\title{
Effect on risk of anencephaly of gene-nutrient interactions between methylenetetrahydrofolate reductase C677T polymorphism and maternal folate, vitamin $B_{12}$ and homocysteine profile
}

\author{
Marina Lacasaña ${ }^{1,2, *}$, Julia Blanco-Muñoz ${ }^{3}$, Victor H Borja-Aburto ${ }^{4}$, Clemente \\ Aguilar-Garduño ${ }^{5}$, Miguel Rodríguez-Barranco ${ }^{1}$, José A Sierra-Ramirez ${ }^{6,7}$, Carlos \\ Galaviz-Hernandez ${ }^{8}$, Beatriz Gonzalez-Alzaga ${ }^{1}$ and Ricardo Garcia-Cavazos ${ }^{6,7}$ \\ ${ }^{1}$ Andalusian School of Public Health, Campus Universitario de la Cartuja, Cuesta del Observatorio 4, CP \\ 18080 Granada, Spain: ${ }^{2}$ CIBER of Epidemiology and Public Health (CIBERESP), Madrid, Spain: ${ }^{3}$ Department \\ of Environmental Health, National Institute of Public Health, Cuernavaca, Mexico: ${ }^{4}$ Occupational Health \\ Coordination, National Medical Center 'Siglo XXI', Mexican Institute of Social Security (IMSS), Mexico DF, \\ Mexico: ${ }^{5}$ Laboratory of Medical Investigations, San Cecilio University Hospital, Granada, Spain: ${ }^{6}$ Department of \\ Training and Medical Education, National Institute of Perinatology, Mexico DF, Mexico: ${ }^{7}$ High School of \\ Medicine, National Institute Polytechnique, Mexico DF, Mexico: ${ }^{8}$ Research Interdisciplinary Center for Integral \\ Regional Development, National Institute Polytechnique, Durango, Mexico
}

Submitted 9 February 2011: Accepted 10 November 2011: First published online 10 January 2012

\begin{abstract}
Objective: To evaluate the effects on anencephaly risk of the interaction between the maternal profile of folate, vitamin $\mathrm{B}_{12}$ and homocysteine and the $677 \mathrm{C} \rightarrow \mathrm{T}$ polymorphism in the gene encoding methylenetetrahydrofolate reductase (MTHFR).

Design: Case-control study paired (1:1) on maternity clinic, date of birth and state of residence. Cases of anencephaly were identified using the Registry of the Mexican Neural Tube Defect Epidemiological Surveillance System. Case and control mothers were selected from the same maternity departments. All mothers completed a structured questionnaire and blood samples were obtained to determine the MTHFR $677 \mathrm{C} \rightarrow \mathrm{T}$ polymorphism and biochemical profile.

Setting: Mexico, Puebla and Guerrero states, Mexico.

Subjects: A total of 151 mothers of cases and controls were enrolled from March 2000 to February 2001. We had complete information on biochemical profile and MTHFR C677T polymorphism for ninety-eight mothers of cases and ninety-one mothers of controls.

Results: The adjusted models show that the risk of anencephaly in mothers with 677TT genotype was reduced by $18 \%(\mathrm{OR}=0 \cdot 82 ; 95 \% \mathrm{CI} 0 \cdot 72,0.94)$ for each $1 \mathrm{ng} / \mathrm{ml}$ increment in serum folate. In terms of tertiles, mothers with 677TT genotype with serum folate levels in the upper tertile $(>14 \cdot 1 \mathrm{ng} / \mathrm{ml})$ had a $95 \%$ lower risk to have a child with anencephaly than mothers with serum folate levels in the first and second tertiles ( $P$ trend $=0 \cdot 012)$.

Conclusions: Our data agree with the hypothesis of a gene-nutrient interaction between $M T H F R 677 \mathrm{C} \rightarrow$ T polymorphism and folate status. We observed a protective effect on anencephaly risk only in mothers with 677TT genotype as serum folate levels increased.
\end{abstract}

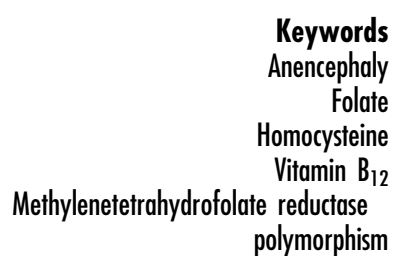

Mexico has one of the highest prevalences of anencephaly in the world, probably due to limited prenatal care and access to elective terminations among others factors, with 5.91 cases per 10000 live births from 2006 to 2008 according to the International Clearinghouse for Birth Defects Monitoring System ${ }^{(1)}$.

The aetiology of neural tube defects (NTD) is multifactorial, including genetic and environmental factors ${ }^{(2,3)}$.
Reports have suggested that the risk of NTD is associated with variants in the gene encoding methylenetetrahydrofolate reductase (MTHFR) as well as other genes involved in folate metabolism (e.g. cystathionine- $\beta$-synthase or methionine synthase reductase) and nutritional status (e.g. folate and vitamin B levels) ${ }^{(4,5)}$. Low levels of folate and vitamin $\mathrm{B}_{12}$, associated with hyperhomocysteinaemia, have been found in mothers of children with NTD. 
However, the findings of different studies have not been consistent $^{(6-12)}$.

MTHFR is an enzyme involved in the metabolism of folic acid via conversion of 5,10-methylenetetrahydrofolate to 5-methyltetrahydrofolate (circulating folate), the methyl donor for methionine synthesis from homocysteine (Hcy). This reaction is catalysed by methionine synthase and uses vitamin $\mathrm{B}_{12}$ as a cofactor. This is important in one-carbon metabolism because methionine is the precursor of $S$-adenosylmethionine, the methyl group donor in more than 100 reactions ${ }^{(13)}$ necessary for DNA synthesis, cell division and tissue growth ${ }^{(4)}$. It is also essential for DNA methylation, which plays an important role in gene expression and chromatin structure ${ }^{(4,14)}$.

The MTHFR gene has two common polymorphisms $(677 \mathrm{C} \rightarrow \mathrm{T}$ and $1298 \mathrm{~A} \rightarrow \mathrm{C}$ ) that reduce activity of the enzyme. The $677 \mathrm{C} \rightarrow \mathrm{T}$ mutation causes an alanine to valine substitution in the predicted catalytic domain of MTHFR, rendering the enzyme thermolabile, with reduced activity under conditions of low folate concentrations ${ }^{(15)}$. Homozygosity for the 677T allele is associated with an increase in plasma Hcy levels and a decreased methyltetrahydrofolate pool, predominantly in states of folate, cobalamin and riboflavin (vitamin $\mathrm{B}_{2}$ ) deficiency ${ }^{(1-19)}$. The other polymorphism, $1298 \mathrm{~A} \rightarrow \mathrm{C}$, which leads to substitution of an adenine by a cytosine, has also been associated with decreased MTHFR enzyme activity, although not as pronounced as that caused by the $677 \mathrm{C} \rightarrow \mathrm{T}$ polymorphism ${ }^{(18,20,21)}$.

The Mexican population has one of the highest frequencies of MTHFR $677 \mathrm{~T}$ allele $(>50 \%)$ in the world $^{(22,23)}$. Previous studies by our group ${ }^{(22)}$ and investigations in other populations in Mexico ${ }^{(24)}$ and elsewhere $^{(25-27)}$ showed an increased risk of anencephaly and other types of NTD in TT homozygous mothers. This homozygosity, in combination with a diet that is deficient in folate or other B vitamins, could increase the risk in women of reproductive age of adverse reproductive effects, including NTD ${ }^{(27-29)}$.

The high prevalence of anencephaly and high frequency of MTHFR 677T allele in the population make Mexico an ideal setting for evaluating the potential effect of gene-nutrient interaction on the risk of this congenital malformation. The objective of the present study was to evaluate the risk of anencephaly associated with the maternal biochemical profile related to the folic acid metabolic pathway and its interaction with MTHFR $677 \mathrm{C} \rightarrow \mathrm{T}$ polymorphism, in three states of Mexico with a high prevalence of anencephaly (Mexico State, Puebla and Guerrero).

\section{Materials and methods}

\section{Design and study population}

The study population and design of the present populationbased case-control study (March 2000-February 2001) are described in detail elsewhere ${ }^{(22,30)}$. Briefly, cases and controls were paired (1:1) on maternity clinic, date of birth and state of residence (Mexico State, Puebla or Guerrero). Cases of anencephaly were identified using the Registry of the Mexican Neural Tube Defect Epidemiological Surveillance System (initials in Spanish, SVEDTN). The SVEDTN forms part of the National Epidemiological Surveillance System, which compiles information from all National Health System institutions, e.g. death certificates. In Mexico, there are two types of death certificate: Foetal Death Certificate for babies born dead; and Death Certificate for post-delivery death.

\section{Selection process}

All cases of death from anencephaly (WHO International Classification of Diseases, 10th revision, code Q00.0) registered in the local SVEDTN between 1 March 2000 and 28 February 2001 were potentially eligible, including live births and stillbirths, with the exception of cases with $<20$ weeks' gestational age, because there is practically no registration of abortions (spontaneous or induced) in Mexico.

For each case, the next child born alive at the same maternity clinic without anencephaly or other congenital malformation was selected as control. Inclusion criteria for cases and controls were residence by the mother in the corresponding state for $\geq 1$ year prior to the birth and the possibility of localizing the mother during the first 3 months postpartum.

During the study period, 189 cases complied with the inclusion criteria, and $157(83 \cdot 1 \%)$ of the mothers agreed to participate in the study. Once a case mother signed a consent form, we contacted the mother of the control or, if she refused participation, the mother of the next eligible control. Contact was made with 160 mothers of controls, 151 of them $(94 \cdot 4 \%)$ agreed to participate. For six cases, it was not possible to find a control fulfilling the inclusion criteria. At the end of this process, we obtained complete information for ninety-eight (51.9\%) mothers of cases and ninety-one $(56.9 \%)$ mothers of controls. Given the sample's size, there is an $81 \%$ power to detect a significant interaction at $95 \%$ confidence for odds ratios equal to those observed in the present study. The software Power version 43 (National Cancer Institute, Bethesda, MD, USA) ${ }^{(31)}$ was used for these calculations.

\section{Data collection}

The questionnaires were applied by the nursing staff previously trained in each of the participating states. Interviews were conducted in the homes of the cases and the controls. The interviewers helped the mothers to define the periconceptional period of interest which was defined as the period from 3 months prior to the last menstruation to 1 month after.

\section{General questionnaire}

A structured questionnaire was administered to mothers of the cases and controls included in the study, containing 
items on sociodemographic characteristics (age, marital/ cohabitant status, maternal education and family income), habits (lifetime and periconceptional use of tobacco and alcohol), presence of chronic or acute disease or fever during periconceptional period, multivitamin supplementation or receipt of medication during periconceptional period, reproductive history (number of pregnancies, history of stillbirths, spontaneous abortions, premature births and malformed children), antenatal care in index pregnancy, family reproductive history, occupational history and domestic exposure to chemical substances during periconceptional period.

Mothers who refused to participate in the study answered a brief questionnaire on their socio-economic characteristics (education, income and occupation) and reproductive history.

\section{FFQ}

A standard FFQ was used to assess dietary intake of nutrients during the periconceptional period. It was developed by Willett et $a l^{(32)}$ and adapted to the Mexican population, validated against $24 \mathrm{~h}$ recalls in a sample of 134 women from Mexico City ${ }^{(33)}$.

\section{Laboratory procedures}

Fasting blood samples were collected from the mothers. All blood samples were drawn before 3 months postpartum. Blood was obtained from the antecubital vein by means of the Vacutainer system, using one tube without anticoagulant for measuring serum folate and serum vitamin $\mathrm{B}_{12}$ and an EDTA tube for measuring plasma levels of total Hcy (t-Hcy) and for DNA extraction. Samples were kept refrigerated at $4^{\circ} \mathrm{C}$ and transported to the National Institute of Perinatology, Mexico DF, where they were centrifuged to separate serum, plasma or buffy coat, which was kept frozen at $-70^{\circ} \mathrm{C}$ until DNA extraction, genotyping and biochemical profile analysis.

\section{Genotyping}

DNA was extracted from leucocytes using a Promega ${ }^{\mathrm{TM}}$ Wizard $^{\circledR}$ Genomic DNA Extraction Kit (Promega Corporation, Madison WI, USA). MTHFR genotype was analysed by PCR in an Eppendorf ${ }^{\mathrm{TM}}$ Mastercycler ${ }^{\circledR}$ Gradient thermal cycler (Eppendorf North America, Hauppauge, NY, USA), using $5 \mu \mathrm{l}$ of 10x PCR Buffer (Promega), $4 \mu \mathrm{l}$ of $25 \mathrm{~mm}-$ $\mathrm{MgCl}_{2}, 2 \cdot 5 \mu \mathrm{l}$ of dimethyl sulfoxide, $1 \mu \mathrm{l}$ of $2 \cdot 5 \mathrm{~mm}$-dNTP mix, 10 pmol of each primer (forward: 5'-GCAGGGAG CTTTGAGGCTGAC-3', reverse: 5'-AGGACGGTGCGGTGA GAGTG-3') and $0.5 \mathrm{U}$ of Taq polymerase (Promega) in a total reaction volume of $50 \mu \mathrm{l}$. PCR conditions were as follows: denaturation at $92^{\circ} \mathrm{C}$ for $1 \mathrm{~min}$, alignment at $60^{\circ} \mathrm{C}$ for $30 \mathrm{~s}$ and extension at $72^{\circ} \mathrm{C}$ for $30 \mathrm{~s}$ ( 35 cycles), followed by a final extension to $72^{\circ} \mathrm{C}(7 \mathrm{~min})$. A $15 \mu$ l aliquot of PCR product was incubated at $37^{\circ} \mathrm{C}$ for $3 \mathrm{~h}$ with $1 \mathrm{U}$ of Hinfl restriction enzyme (New England Biolabs ${ }^{\circledR}$ Inc., Ipswich MA, USA). Restriction fragments were electrophoresed in a
$4 \%(\mathrm{w} / \mathrm{v})$ agarose gel stained with ethidium bromide and visualized under UV light in a Fotodyne ${ }^{\mathrm{TM}}$ transilluminator (Fotodyne $^{\circledR}$ Inc., Hartland, WI, USA).

Genotyping was performed simultaneously by two technicians and then the results were contrasted.

Determination of red blood cell folate, serum folate, serum vitamin $B_{12}$ and plasma total homocysteine Serum folate and red blood cell (RBC) folate were quantified by means of ionic capture using an IMx analyser (Abbott IMx Folate; Abbott Laboratories, Diagnostic Division, Abbott Park, IL, USA). This assay is based on the formation of polyanion-analyte complexes with a negative charge captured through an electrostatic interaction with the matrix, which has a positive electrical charge ${ }^{(34)}$. It is necessary to determine the haematocrit value of each patient and to perform a previous haemolysis to quantify RBC folate.

Vitamin $\mathrm{B}_{12}$ was determined by microparticle enzyme immunoassay (Abbott IMx Vitamin $\mathrm{B}_{12}$; Abbott Laboratories, Diagnostic Division), which uses microparticles coated with an intrinsic factor for vitamin $\mathrm{B}_{12}{ }^{(35)}$.

Plasma t-Hcy levels were quantified by fluorescence polarization immunoassay technology using the IMx system $^{(36)}$. Laboratory reference values were $175-700 \mathrm{ng} / \mathrm{ml}$ for RBC folate, 3-17 ng/ml for serum folate, $200-950 \mathrm{pg} / \mathrm{ml}$ for vitamin $B_{12}$ and $5-16 \mu \mathrm{mol} / 1$ for plasma t-Hcy.

Genotyping and analyses of biochemical profile were performed blind to case and control status.

\section{Etbics approval}

The study was approved by the Institutional Review Board of the National Institute of Public Health of Mexico. All participants were given an informed consent letter, which was signed before participation.

\section{Statistical analysis}

Differences in sociodemographic, reproductive and lifestyle variables and in folate and vitamin $\mathrm{B}_{12}$ intakes were compared between mothers of cases and controls by using the $\chi^{2}$ test or, if applicability conditions were not met, by Fisher's exact test.

Concentrations of serum folate, RBC folate, serum vitamin $\mathrm{B}_{12}$ and plasma t-Hcy (medians, means and standard deviations) were compared between mothers of cases and controls as a function of MTHFR $677 \mathrm{C} \rightarrow \mathrm{T}$ polymorphism by means of the Kruskal-Wallis non-parametric test, because the distribution of these compounds was skewed to the right and did not fulfil normality criteria (Kolmogorov-Smirnov test). The differences in biochemical profile between case mothers and control mothers were evaluated by means of the Mann-Whitney non-parametric test.

A Spearman correlation analysis was developed between the levels of serum folate, RBC folate, serum vitamin $\mathrm{B}_{12}$ and plasma t-Hcy, because these variables did not have a normal distribution. The Kolmogorov-Smirnov 
test was applied to assess the normal distribution of the variables.

A multivariate unconditional logistic regression model was constructed to assess the risk of anencephaly associated with maternal concentrations of serum folate, RBC folate, serum vitamin $\mathrm{B}_{12}$ and plasma $\mathrm{t}-\mathrm{Hcy}$, including the genotype-nutrient interactions between the maternal biochemical profile (as continuous variables) and MTHFR $677 \mathrm{C} \rightarrow \mathrm{T}$ polymorphisms. We constructed both a nonadjusted model and a model adjusted for the following confounding variables: state of residence, age of the mother, social status, reproductive history, exposure to agricultural work, and daily intake during the periconceptional period of folate, vitamin $\mathrm{B}_{12}$ and total energy.

Finally, unconditional logistic regression models were constructed that only included genotype-serum folate interactions. Two distinct approaches were applied: (i) considering serum folate levels as a continuous variable to evaluate the change in risk per unit increase; and (ii) considering the continuous variable in terms of tertiles of serum folate in the controls in order to compare the risk between mothers with high $v$. low levels of serum folate. In both cases, a non-adjusted model and a model adjusted for confounders were constructed.

We applied the following criteria for inclusion of potential confounding variables in the multivariate model: (i) all the variables associated with anencephaly in the bivariate models with $P<0 \cdot 20$ were selected to evaluate the presence of confounding; (ii) multivariate models were constructed adding the previously selected variables, including in the final model all those variables associated with anencephaly with $P<0 \cdot 10$.

The level of significance was set at 0.05 and $95 \%$ confidence intervals were calculated for odds ratios. SPSS version 14 (SPSS Inc, Chicago, IL, USA) and STATA version 7 (StataCorp LP, College Station, TX, USA) statistical software packages were used for the analyses.

\section{Results}

We had complete information on MTHFR $677 \mathrm{C} \rightarrow \mathrm{T}$ polymorphisms and serum folate levels for 189 mothers, ninety-eight case mothers and ninety-one control mothers. No significant differences in variables of interest were found between mothers with available data on genotype and biochemical profile and those without these data. Moreover, the distribution of genotypes for MTHFR $677 \mathrm{C} \rightarrow \mathrm{T}$ among controls was in Hardy-Weinberg equilibrium $(P=0.83)$.

Table 1 displays the main characteristics of case and control mothers in relation to the risk of anencephaly, showing significant differences. Case mothers were more often 35 years of age or older, had a lower income, were more often multipara, more often had a history of adverse events, and more frequently reported having worked in agriculture some time in life. The mean gestational age was significantly lower than in controls $(7 \cdot 8$ months $v$. $8 \cdot 9$ months).

The median folate intake of case mothers $(299 \cdot 3 \mu \mathrm{g} / \mathrm{d})$ and control mothers $(330 \mu \mathrm{g} / \mathrm{d})$ was about $50 \%$ of the RDA for pregnant women ${ }^{(37)}(600 \mu \mathrm{g} / \mathrm{d})$.

The Spearman correlation analysis showed a significant positive correlation between serum folate levels, RBC folate and vitamin $\mathrm{B}_{12}$, and a significant negative correlation between maternal concentrations of these nutrients and plasma t-Hcy levels. The highest correlation coefficient was observed between maternal levels of serum folate and RBC folate $(r=0.534)$. The same pattern was observed in both cases and controls (data not presented).

Median levels of RBC folate, serum folate, serum vitamin $B_{12}$ and plasma t-Hcy were within the laboratory reference range and did not differ significantly between case and control mothers $(P>0.05)$. The percentage of cases and controls below the reference range were as follows: serum folate, $2 \%$ of cases and $0 \%$ of controls; RBC folate, $20 \%$ of cases and $22 \%$ of controls; vitamin $\mathrm{B}_{12}, 11 \%$ of cases and $8 \%$ of controls. Also, $26 \%$ of cases and $18 \%$ of controls had t-Hcy levels above the reference range.

However, when stratified according to MTHFR $677 \mathrm{C} \rightarrow$ $\mathrm{T}$ polymorphism, case mothers with 677TT genotype showed significantly lower levels of serum folate and serum vitamin $\mathrm{B}_{12}$ compared with case mothers with 677CC and 677CT genotypes. t-Hcy levels were significantly higher in case mothers with 677TT genotype than in the other case mothers. In contrast, control mothers showed no differences in serum folate, RBC folate, serum vitamin $\mathrm{B}_{12}$ or plasma t-Hcy levels as a function of the MTHFR $677 \mathrm{C} \rightarrow$ T polymorphism (Table 2 ).

Comparison of serum folate levels in case and control mothers according to the MTHFR $677 \mathrm{C} \rightarrow \mathrm{T}$ polymorphism showed that only the case mothers with 677TT genotype had significantly lower serum folate levels compared with control mothers (median values: $8 \cdot 2 v$. 14.1, $P=0 \cdot 004$ ). However, median RBC folate levels were significantly higher in case mothers with 677CT than in the control mothers (medians: $311 \cdot 7$ v. 206.2, $P=0 \cdot 026$ ), with no differences among remaining genotypes. No significant differences in median serum vitamin $\mathrm{B}_{12}$ and plasma t-Hcy concentrations were found in cases or controls as a function of the MTHFR $677 \mathrm{C} \rightarrow \mathrm{T}$ polymorphism (Table 2).

Table 3 shows the odds ratios for anencephaly in the unconditional logistic regression model that included genotype-nutrient interactions between the mother's biochemical profile and the MTHFR $677 \mathrm{C} \rightarrow \mathrm{T}$ polymorphism. After adjusting for state of residence, childbirth health-care centre, age, social status, reproductive history, exposure to agricultural work at some time in life and daily dietary intake of folate, vitamin $\mathrm{B}_{12}$ and total energy during the periconceptional period, a significant interaction was found between MTHFR $677 \mathrm{C} \rightarrow \mathrm{T}$ polymorphism and serum folate levels $(P=0 \cdot 02)$, while the interaction between 
Table 1 Sociodemographic, reproductive and lifestyle characteristics of mothers of anencephaly cases and controls, Mexico, Puebla and Guerrero states, Mexico, March 2000-February 2001

\begin{tabular}{|c|c|c|c|c|c|}
\hline & \multicolumn{2}{|c|}{ Cases } & \multicolumn{2}{|c|}{ Controls } & \multirow[b]{2}{*}{$P$ value } \\
\hline & $n$ & $\%$ & $n$ & $\%$ & \\
\hline Total & 98 & 100 & 91 & 100 & \\
\hline \multicolumn{6}{|l|}{ Age } \\
\hline$<35$ years & 89 & $90 \cdot 8$ & 89 & $97 \cdot 8$ & \\
\hline$\geq 35$ years & 9 & $9 \cdot 2$ & 2 & $2 \cdot 2$ & $0 \cdot 040 \ddagger$ \\
\hline \multicolumn{6}{|l|}{ Social status } \\
\hline$\leq 1000$ pesos/month $\& \leq 9$ years of education & 48 & $49 \cdot 0$ & 22 & $24 \cdot 7$ & \\
\hline$>1000$ pesos $/$ month $\& \leq 9$ years of education & 30 & $30 \cdot 6$ & 34 & $38 \cdot 2$ & \\
\hline$\leq 1000$ pesos/month $\&>9$ years of education & 4 & $4 \cdot 1$ & 6 & $6 \cdot 7$ & \\
\hline$>1000$ pesos/month $\&>9$ years of education & 16 & $16 \cdot 3$ & 27 & $30 \cdot 3$ & $0.005 \ddagger$ \\
\hline \multicolumn{6}{|l|}{ Reproductive history } \\
\hline Primiparous & 37 & $37 \cdot 8$ & 44 & $49 \cdot 4$ & \\
\hline Multiparous, without history of adverse events* & 33 & $33 \cdot 7$ & 35 & $39 \cdot 3$ & \\
\hline Multiparous, with history of adverse events ${ }^{*}$ & 28 & $28 \cdot 6$ & 10 & $11 \cdot 2$ & $0 \cdot 012 \ddagger$ \\
\hline \multicolumn{6}{|l|}{ Agricultural occupation at some time in life } \\
\hline No & 72 & $73 \cdot 5$ & 74 & $81 \cdot 3$ & \\
\hline Yes & 26 & $26 \cdot 5$ & 17 & $18 \cdot 7$ & $0 \cdot 198 \ddagger$ \\
\hline \multicolumn{6}{|l|}{ Intake of folic acidt } \\
\hline$\geq 600 \mu \mathrm{g} / \mathrm{d}$ & 15 & $16 \cdot 0$ & 19 & $21 \cdot 3$ & \\
\hline$<600 \mu \mathrm{g} / \mathrm{d}$ & 79 & $84 \cdot 0$ & 70 & $78 \cdot 7$ & $0.349 \ddagger$ \\
\hline \multicolumn{6}{|l|}{ Intake of vitamin $\mathrm{B}_{12}{ }^{\dagger}$} \\
\hline$\geq 2.6 \mu \mathrm{g} / \mathrm{d}$ & 53 & $56 \cdot 4$ & 55 & $61 \cdot 8$ & \\
\hline$<2.6 \mu \mathrm{g} / \mathrm{d}$ & 41 & $43 \cdot 6$ & 34 & $38 \cdot 2$ & $0 \cdot 457 \ddagger$ \\
\hline \multicolumn{6}{|l|}{ Consumption of alcohol in periconceptional period } \\
\hline No & 93 & $94 \cdot 9$ & 83 & $91 \cdot 2$ & \\
\hline Yes & 5 & $5 \cdot 1$ & 8 & $8 \cdot 8$ & $0 \cdot 317 \ddagger$ \\
\hline \multicolumn{6}{|l|}{ Consumption of tobacco in periconceptional period } \\
\hline No & 97 & $99 \cdot 0$ & 86 & $94 \cdot 5$ & \\
\hline Yes & 1 & $1 \cdot 0$ & 5 & $5 \cdot 5$ & $0 \cdot 107 \S$ \\
\hline
\end{tabular}

*Includes stilbirths, premature births, congenital malformations and abortions.

thimits selected in accordance with current daily recommendations for folate and vitamin $\mathrm{B}_{12}$ intake by pregnant women ${ }^{(37)}$.

$\ddagger \chi^{2}$ test.

§Fisher's exact test.

Table 2 Maternal serum and RBC levels of folate, vitamin $\mathrm{B}_{12}$ and $\mathrm{t}-\mathrm{Hcy}$ as a function of the MTHFR $677 \mathrm{C} \rightarrow \mathrm{T}$ polymorphism among mothers of anencephaly cases and controls, Mexico, Puebla and Guerrero states, Mexico, March 2000-February 2001

\begin{tabular}{|c|c|c|c|c|c|c|c|c|c|}
\hline & \multicolumn{4}{|c|}{ Cases $(n 98)$} & \multicolumn{4}{|c|}{ Controls ( $n$ 91) } & \multirow[b]{2}{*}{$P$ value } \\
\hline & $n$ & Mean & SD & Median & $n$ & Mean & SD & Median & \\
\hline \multicolumn{10}{|c|}{ Serum folate $(\mathrm{ng} / \mathrm{ml})$} \\
\hline CC & 11 & $16 \cdot 7$ & $6 \cdot 4$ & $17 \cdot 9 \dagger$ & 20 & $12 \cdot 0$ & $6 \cdot 3$ & $12 \cdot 4$ & 0.06 \\
\hline CT & 45 & $13 \cdot 6$ & $5 \cdot 9$ & $12 \cdot 8+$ & 49 & $12 \cdot 4$ & $7 \cdot 2$ & $10 \cdot 2$ & $0 \cdot 16$ \\
\hline TT & 42 & $9 \cdot 1$ & $5 \cdot 8$ & $8 \cdot 2 t$ & 22 & $14 \cdot 2$ & 6.9 & $14 \cdot 1$ & 0.004 \\
\hline All genotypes & 98 & $12 \cdot 0$ & $6 \cdot 5$ & $10 \cdot 8$ & 91 & $12 \cdot 7$ & 6.9 & $10 \cdot 8$ & 0.60 \\
\hline \multicolumn{10}{|c|}{ RBC folate $(\mathrm{ng} / \mathrm{ml})$} \\
\hline $\mathrm{CC}$ & 10 & $448 \cdot 2$ & $430 \cdot 6$ & $301 \cdot 1$ & 19 & $294 \cdot 9$ & $245 \cdot 8$ & $215 \cdot 4$ & $0 \cdot 17$ \\
\hline CT & 46 & $358 \cdot 8$ & $186 \cdot 0$ & $311 \cdot 7$ & 47 & $303 \cdot 4$ & $217 \cdot 0$ & $206 \cdot 2$ & 0.03 \\
\hline $\mathrm{TT}$ & 42 & $273 \cdot 7$ & $121 \cdot 9$ & $256 \cdot 8$ & 22 & $340 \cdot 6$ & $205 \cdot 3$ & $243 \cdot 8$ & 0.34 \\
\hline All genotypes & 98 & $331 \cdot 5$ & $206 \cdot 7$ & $292 \cdot 7$ & 88 & $310 \cdot 9$ & $218 \cdot 8$ & $226 \cdot 3$ & $0 \cdot 10$ \\
\hline \multicolumn{10}{|c|}{ Serum vitamin $B_{12}(\mathrm{pg} / \mathrm{ml})$} \\
\hline $\mathrm{CC}$ & 11 & $807 \cdot 6$ & $604 \cdot 0$ & $661 \cdot 9+$ & 20 & $550 \cdot 3$ & $424 \cdot 8$ & $416 \cdot 2$ & 0.09 \\
\hline CT & 46 & $585 \cdot 2$ & $556 \cdot 2$ & $450 \cdot 9+$ & 49 & $620 \cdot 3$ & $594 \cdot 2$ & $420 \cdot 9$ & 0.89 \\
\hline TT & 42 & $485 \cdot 0$ & $477 \cdot 2$ & $319 \cdot 9+$ & 22 & $577 \cdot 2$ & $492 \cdot 1$ & $442 \cdot 4$ & $0 \cdot 22$ \\
\hline All genotypes & 99 & $567 \cdot 4$ & $533 \cdot 0$ & $434 \cdot 5$ & 91 & $594 \cdot 5$ & $532 \cdot 7$ & $420 \cdot 9$ & 0.59 \\
\hline \multicolumn{10}{|l|}{ t-Hcy (mmol/l) } \\
\hline CC & 12 & $13 \cdot 5$ & $10 \cdot 9$ & $9 \cdot 6+$ & 15 & $11 \cdot 7$ & $4 \cdot 4$ & $10 \cdot 1$ & 0.66 \\
\hline CT & 41 & $10 \cdot 9$ & $4 \cdot 7$ & $9 \cdot 9 t$ & 44 & $11 \cdot 7$ & $6 \cdot 3$ & $10 \cdot 0$ & 0.98 \\
\hline $\mathrm{TT}$ & 35 & $17 \cdot 3$ & $10 \cdot 2$ & $13 \cdot 8 t$ & 25 & $13 \cdot 9$ & $6 \cdot 5$ & $12 \cdot 6$ & 0.36 \\
\hline All genotypes & 88 & $13 \cdot 8$ & $8 \cdot 6$ & $11 \cdot 0$ & 84 & $12 \cdot 4$ & $6 \cdot 1$ & $11 \cdot 1$ & 0.58 \\
\hline
\end{tabular}

RBC, red blood cell; MTHFR, methylenetetrahydrofolate reductase gene; t-Hcy, total homocysteine.

Laboratory reference range: serum folate, $3-17 \mathrm{ng} / \mathrm{ml}$; RBC folate, $175-700 \mathrm{ng} / \mathrm{ml}$; vitamin $\mathrm{B}_{12}$, 200-950 pg/ml; homocysteine, 5-15 mmol/l.

${ }^{*}$ Comparison between case and control mothers of the same genotype by Mann-Whitney test.

+Values were significantly different among genotypes (Kruskal-Wallis test): $P<0.05$. 
Table 3 Logistic regression models for the risk of anencephaly with interaction between biochemical profile (serum folate, RBC folate, vitamin $\mathrm{B}_{12}$ and t-Hcy levels) and the MTHFR 677C $\rightarrow$ T polymorphism, Mexico, Puebla and Guerrero states, Mexico, March 2000-February 2001

\begin{tabular}{|c|c|c|c|c|c|c|}
\hline & Crude OR & $95 \% \mathrm{Cl}$ & $P$ value & Adjusted OR* & $95 \% \mathrm{Cl}$ & $P$ value \\
\hline CT genotypet & $1 \cdot 98$ & $0 \cdot 67,5 \cdot 87$ & $0 \cdot 22$ & $4 \cdot 01$ & $0.51,31 \cdot 68$ & $0 \cdot 19$ \\
\hline TT genotypet & $3 \cdot 31$ & $1 \cdot 05,10 \cdot 49$ & 0.04 & $9 \cdot 84$ & $1 \cdot 13,85 \cdot 95$ & 0.04 \\
\hline Serum folate & $1 \cdot 05$ & $0 \cdot 86,1 \cdot 28$ & 0.63 & $1 \cdot 12$ & $0 \cdot 88,1 \cdot 43$ & $0 \cdot 35$ \\
\hline RBC folate & $1 \cdot 001$ & $0.997,1.003$ & 0.93 & 0.99 & $0.98,1.01$ & 0.41 \\
\hline Serum vitamin $B_{12}$ & $1 \cdot 001$ & $0.999,1.003$ & 0.46 & $1 \cdot 003$ & $0.999,1.007$ & 0.09 \\
\hline t-Hcy & $1 \cdot 05$ & $0.93,1 \cdot 19$ & 0.46 & $1 \cdot 06$ & $0 \cdot 90,1 \cdot 26$ & 0.47 \\
\hline Serum folate $\times$ CT genotypet & 0.98 & $0 \cdot 79,1 \cdot 22$ & 0.87 & 0.90 & $0 \cdot 69,1 \cdot 18$ & $0 \cdot 47$ \\
\hline Serum folate $\times$ TT genotypet & $0 \cdot 82$ & $0 \cdot 65,1 \cdot 03$ & 0.09 & 0.68 & $0.49,0.94$ & 0.02 \\
\hline RBC folate $\times$ CT genotypet & $1 \cdot 001$ & $0.997,1.006$ & 0.55 & $1 \cdot 01$ & $0.99,1.03$ & $0 \cdot 32$ \\
\hline RBC folate $\times$ TT genotypet & $1 \cdot 002$ & $0.996,1.008$ & 0.58 & $1 \cdot 01$ & $0.99,1.03$ & $0 \cdot 28$ \\
\hline Serum vitamin $\mathrm{B}_{12} \times \mathrm{CT}$ genotypet & 0.999 & $0.997,1 \cdot 001$ & $0 \cdot 28$ & 0.996 & $0.993,1.000$ & 0.06 \\
\hline Serum vitamin $B_{12} \times$ TT genotypet & $1 \cdot 000$ & $0.997,1.002$ & $0 \cdot 82$ & 0.999 & $0.995,1.003$ & 0.51 \\
\hline t-Hcy $\times$ CT genotypet & 0.94 & $0 \cdot 80,1 \cdot 10$ & 0.42 & 0.91 & $0 \cdot 75,1 \cdot 11$ & 0.36 \\
\hline t-Hcy $\times$ TT genotypet & 0.99 & $0 \cdot 85,1 \cdot 16$ & 0.93 & 0.95 & $0 \cdot 77,1 \cdot 16$ & 0.59 \\
\hline
\end{tabular}

MTHFR, methylenetetrahydrofolate reductase gene; RBC, red blood cell; t-Hcy, total homocysteine.

Interpretation of the model: the OR for serum folate levels $(\mathrm{OR}=1 \cdot 12)$ is the probability of having a child with anencephaly for each $1 \mathrm{ng} / \mathrm{ml}$ increase in serum folate in women with CC genotype (reference level for the MTHFR $677 \mathrm{C} \rightarrow$ T polymorphism); the same applies to the OR for RBC folate, vitamin $\mathrm{B}_{12}$ and serum t-Hcy.

The risk of having an anencephalic child associated with a $1 \mathrm{ng} / \mathrm{ml}$ increase in serum folate in mothers with CT genotype is calculated by multiplying the OR associated with serum folate levels $(O R=1 \cdot 12)$ by the $O R$ associated with 'Serum folate $\times C T$ genotype' $(O R=0.90)$, OR $=1 \cdot 12 \times 0.90=1 \cdot 01$. The same procedure is applicable for 'Serum folate $\times$ TT genotype', OR $=1 \cdot 12 \times 0 \cdot 68=0 \cdot 76$. The same applies to the OR for the other interaction terms.

${ }^{\star}$ Adjusted by maternal characteristics: state of residence, childbirth health-care centre, age, social status, reproductive history, agricultural work at some time in life, and daily intake of folate, vitamin $\mathrm{B}_{12}$ and total energy during the periconceptional period.

tGenotype CC is the reference level.

Table 4 Crude and adjusted odds ratios and $95 \%$ confidence intervals for the risk of anencephaly by the interaction between serum folate levels and the MTHFR 677C $\rightarrow$ T polymorphism, Mexico, Puebla and Guerrero states, Mexico, March 2000-February 2001

\begin{tabular}{|c|c|c|c|c|c|c|}
\hline & \multicolumn{6}{|c|}{ MTHFR $677 \mathrm{C} \rightarrow \mathrm{T}$ polymorphism } \\
\hline & \multicolumn{2}{|c|}{$\mathrm{CC}$} & \multicolumn{2}{|c|}{ CT } & \multicolumn{2}{|c|}{ TT } \\
\hline & OR & $95 \% \mathrm{Cl}$ & OR & $95 \% \mathrm{Cl}$ & OR & $95 \% \mathrm{Cl}$ \\
\hline Crude interaction models & \multicolumn{2}{|c|}{$(n 31)$} & \multicolumn{2}{|c|}{$(n 94)$} & \multicolumn{2}{|c|}{$(n 64)$} \\
\hline Increment of $1 \mathrm{ng} / \mathrm{ml}$ & $1 \cdot 13$ & $0.99,1.29$ & 1.03 & $0.97,1 \cdot 10$ & $0 \cdot 89$ & $0.81,0.97$ \\
\hline First tertile $(<8.2 \mathrm{ng} / \mathrm{ml})$ & $1 \cdot 00$ & Ref. & $1 \cdot 00$ & Ref. & $1 \cdot 00$ & Ref. \\
\hline Second tertile $(8 \cdot 2-14 \cdot 1 \mathrm{ng} / \mathrm{ml})$ & 0.80 & $0.06,11 \cdot 30$ & $2 \cdot 10$ & $0 \cdot 67,5 \cdot 87$ & 0.91 & $0.24,3.54$ \\
\hline Third tertile $(>14 \cdot 1 \mathrm{ng} / \mathrm{ml})$ & $4 \cdot 57$ & $0 \cdot 72,29 \cdot 13$ & 1.99 & $0.67,5.87$ & $0 \cdot 13$ & $0.03,0.52$ \\
\hline Adjusted interaction models* & \multicolumn{2}{|c|}{$(n 22)$} & \multicolumn{2}{|c|}{$(n 66)$} & \multicolumn{2}{|c|}{ (n 48) } \\
\hline Increment of $1 \mathrm{ng} / \mathrm{ml}$ & 1.06 & $0 \cdot 89,1 \cdot 27$ & 1.02 & $0.92,1 \cdot 13$ & $0 \cdot 82$ & $0.72,0.94$ \\
\hline First tertile $(<8 \cdot 2 \mathrm{ng} / \mathrm{ml})$ & $1 \cdot 00$ & Ref. & $1 \cdot 00$ & Ref. & $1 \cdot 00$ & Ref. \\
\hline Second tertile $(8 \cdot 2-14 \cdot 1 \mathrm{ng} / \mathrm{ml})$ & $2 \cdot 77$ & $0.11,68.09$ & $2 \cdot 38$ & $0.47,11.93$ & $0 \cdot 85$ & $0 \cdot 13,5 \cdot 42$ \\
\hline Third tertile $(>14.1 \mathrm{ng} / \mathrm{ml})$ & $2 \cdot 12$ & $0 \cdot 19,23 \cdot 18$ & 1.93 & $0.35,10.77$ & 0.05 & $0.01,0.37$ \\
\hline
\end{tabular}

MTHFR, methylenetetrahydrofolate reductase gene; RBC, red blood cell; t-Hcy, total homocysteine; Ref., referent category.

${ }^{*}$ Adjusted by maternal characteristics: state of residence, childbirth health-care centre, age, social status, reproductive history, agricultural work at some time in life, RBC folate level, serum vitamin $B_{12}$ level, plasma $t-H c y$ level, and daily intake of folate, vitamin $B_{12}$ and total energy during the periconceptional period.

this polymorphism and RBC folate, vitamin $\mathrm{B}_{12}$ or $\mathrm{t}-\mathrm{Hcy}$ levels was not significant.

Table 4 shows the results of the models of the interaction between serum folate and MTHFR $677 \mathrm{C} \rightarrow \mathrm{T}$ polymorphism. The adjusted models show that the risk of anencephaly in mothers with 677TT genotype was reduced by $18 \%(\mathrm{OR}=0 \cdot 82 ; 95 \% \mathrm{CI} 0 \cdot 72,0.94)$ for each $1 \mathrm{ng} / \mathrm{ml}$ increment in serum folate. However, in mothers with 677CC and 677CT genotypes, an increase in serum folate levels did not significantly reduce this risk. In terms of tertiles, mothers with 677TT genotype with serum folate levels in the upper tertile $(>14 \cdot 1 \mathrm{ng} / \mathrm{ml})$ had a $95 \%$ lower risk $(\mathrm{OR}=0 \cdot 05 ; 95 \% \mathrm{CI} 0 \cdot 01,0 \cdot 37) v$. those with levels in the lowest tertile $(<8 \cdot 2 \mathrm{ng} / \mathrm{ml} ; P$ trend $=0 \cdot 012)$.

\section{Discussion}

Maternal nutritional factors, especially folic acid intake, are known to make a substantive contribution to reduce the probability of occurrence or recurrence of the birth of a child with NTD. However, the aetiology of NTD has not been fully elucidated. In the present study, no significant differences were found between mothers of anencephaly cases and mothers of controls in median postpartum concentrations of serum folate, RBC folate, serum vitamin $\mathrm{B}_{12}$ and plasma homocysteine. However, evaluation of the potential effect of the interaction between biochemical profile and $M T H F R$ $677 \mathrm{C} \rightarrow \mathrm{T}$ polymorphism showed a significant protective effect for each $1 \mathrm{ng} / \mathrm{ml}$ increment 
in serum folate levels among mothers with 677TT genotype (adjusted OR $=0.82 ; 95 \% \mathrm{CI} 0 \cdot 72,0 \cdot 94$ ).

Inconsistent results have been published on the protective effect of folate. Thus, some studies showed similar serum folate levels between mothers of children with NTD and mothers of controls ${ }^{(6,8-10)}$, whereas others reported lower serum folate levels in case $v$. control mothers ${ }^{(11,38)}$. There has even been a recent report from Brazil of significantly lower serum folate levels in control mothers and their children than in mothers of NTD patients and the NTD patients themselves, which the authors attributed to a greater dietary intake of folate by the case group ${ }^{(7)}$.

Median RBC folate levels were similar between case and control mothers in the present study, as also observed in other Mexican populations ${ }^{(8,9)}$, although Martinez-Villarreal et al. ${ }^{(9)}$ observed a higher percentage of case than control mothers with RBC folate levels $<160 \mathrm{ng} / \mathrm{ml}$. However, studies in other countries reported significantly lower RBC folate concentrations in case mothers than in control mothers ${ }^{(10-12,38-40)}$.

Evidence has emerged over the past few decades of an independent role for vitamin $B_{12}$ in NTD risk, with numerous studies reporting significantly lower vitamin $B_{12}$ levels in mothers of NTD cases compared with control mothers $^{(6-8,10,11,36)}$. However, vitamin $\mathrm{B}_{12}$ levels were similar between case and control mothers in the present study, although the percentage of mothers with vitamin $\mathrm{B}_{12}$ deficiency $(<200 \mathrm{pg} / \mathrm{ml})$ was slightly higher in cases than in controls $(57 \cdot 9 \% v \cdot 42 \cdot 1 \%)$.

A limitation of many of the above studies was that they did not jointly consider the effect of the genotype and biochemical profile of the mothers. In our study, stratification by MTHFR $677 \mathrm{C} \rightarrow \mathrm{T}$ polymorphism showed that case mothers with 677TT genotype had significantly lower levels of serum folate and serum vitamin $\mathrm{B}_{12}$ and significantly higher levels of t-Hcy in comparison with case mothers with 677CC and 677CT genotypes, with a lower intake of folate and vitamin $\mathrm{B}_{12}$ by case mothers with 677TT genotype compared with the other case mothers. However, the control mothers showed no significant difference in biochemical profile as a function of the MTHFR $677 \mathrm{C} \rightarrow \mathrm{T}$ polymorphism, probably because there were no differences in folate or vitamin $\mathrm{B}_{12}$ intake as a function of the genotype. This finding supports the hypothesis that serum levels of folate and vitamin $B_{12}$ can be attributed to both genetic and nutritional factors ${ }^{(10,41)}$.

However, case and control mothers with 677TT genotype showed no significant differences in median RBC folate concentrations compared with mothers with 677CT and CC genotypes $(P=0.103$ and $P=0.354$ for cases and controls, respectively), as also reported by other authors $^{(10,20,42,43)}$.

Finally, in the multivariate analysis a significant effect was found for the interaction between serum folate levels and MTHFR $677 \mathrm{C} \rightarrow \mathrm{T}$ polymorphism, but not for the interaction between RBC folate, serum vitamin $B_{12}$ and plasma t-Hcy levels. The case mothers with 677TT genotype and serum folate levels $>14 \cdot 1 \mathrm{ng} / \mathrm{ml}$ (third tertile) showed a $95 \%$ reduction in the risk of having a child with anencephaly $v$. those with levels $<8.2 \mathrm{ng} / \mathrm{ml}$ (first tertile), and a significant dose-response relationship was observed (OR $=0 \cdot 05 ; 95 \%$ CI 0.01, 0.37; $P$ trend $=0 \cdot 012$ ). Although numerous studies have suggested this effect of the interaction between this MTHFR polymorphism and folate status on the risk of NTD, the small sample size of most of them prevented a statistical analysis of this interaction. Only Christensen et $a l^{(10)}$ analysed this interaction in a study in Montreal of children with NTD and their mothers in comparison with a control group. They reported a higher risk of NTD for children with 677TT genotype and low RBC folate levels $(\mathrm{OR}=13.43$; $95 \%$ CI $2 \cdot 49,72 \cdot 83$ ), although the difference in maternal levels did not reach significance (OR $=3 \cdot 28 ; 95 \%$ CI 0.84, 12·85). Nevertheless, some human and animal studies did not find any effect of this interaction ${ }^{(7,44,45)}$.

The mechanism by which the 677TT genotype and serum folate levels increase the risk of anencephaly has yet to be elucidated. In the present study, the case mothers with 677TT genotype and serum folate levels $<10.4 \mathrm{ng} / \mathrm{ml}$ (median value in controls) had higher t-Hcy levels than the other case mothers $(P<0 \cdot 07)$. However, in the multivariate model no interaction effect between the 677TT genotype and plasma homocysteine levels was observed. So, although a teratogenic effect has been attributed to $\mathrm{Hcy}^{(46,47)}$, this hypothetical mechanism does not seem to be reflected in the results of our study. Heidenreich et al. ${ }^{(48)}$ demonstrated that the increase in intracellular $\mathrm{Ca}^{2+}$ signalling could be responsible for the above-mentioned teratogenic effect.

Human and animal studies have shown that the cause of NTD is multifactorial and that folate metabolism, although important, is not the only factor ${ }^{(49)}$. Although polymorphism in other genes involved in folate metabolism (e.g. methionine synthase reductase (MTRR) $66 \mathrm{~A} \rightarrow \mathrm{G}$ ) appeared to be a potential risk factor for $\mathrm{NTD}^{(50)}$ and mutated homozygotes for $66 \mathrm{~A} \rightarrow \mathrm{G}$ have hyperhomocysteinaemia $^{(51,52)}$, no association with NTD was found in the study of three different polymorphisms in MTRR performed by O'Leary et al. ${ }^{(53)}$.

Until now, more than 200 genes have been found to be involved in the development of NTD in the mouse, some of them being energy metabolism gene (UCP2), vitamin $\mathrm{B}$ metabolism (Transcoalbumin), over-expression of sonic hedgehog signalling and loss of function of non-canonical Wnt gene $^{(3,14)}$.

In our study population, serum folate, RBC folate, vitamin $\mathrm{B}_{12}$ and $\mathrm{t}$-Hcy levels were measured before 3 months postpartum; therefore they may not reflect levels during the periconceptional period, specifically up to day 25 of gestation when the neural tube closes at its rostral pole ${ }^{(54)}$. Moreover, the mean gestational age was significantly lower 
in cases ( 7.8 months) than in controls ( 8.9 months), and therefore serum folate, $\mathrm{RBC}$ folate and vitamin $\mathrm{B}_{12}$ were likely higher in cases than in controls at the end of the pregnancy and thus in the postpartum period. Nevertheless, vitamin $\mathrm{B}_{12}$, RBC folate and Hcy concentrations return to periconceptional levels at 6 weeks postpartum ${ }^{(54)}$. On the other hand, although serum folate levels also show a slight decrease during pregnancy, they do not reach periconceptional levels until 6 months postpartum ${ }^{(55)}$. This can be explained by the haemodilution process produced during pregnancy, by lactation, by hormonal influences or by oral contraception methods ${ }^{(56-58)}$. Therefore, a potential bias due to gestational age and lactation (only controls are breast-fed) may lead to an underestimation of the effect of the associations observed. In fact, the effect of folic acid deficiency on anencephaly risk and the effect of interaction with the TT genotype may be even greater than reported herein.

One of the limitations of our study is that specific information regarding the ethnicity of the women was not available, thus we cannot rule out the presence of ethnic stratification, nor control for this factor in the analysis; this could have led to a certain degree of residual confounding. However, given that each control was selected from the same state and in the same childbirth health-care centre where the case was identified, we think that both come from the same population and that, if stratification exists, the distribution of the strata would be similar between the case and the control mothers and the value of association would not be biased.

Another potential limitation of the study could be if the biochemical profile established for the mothers was influenced by a differential multivitamin supplementation at postpartum between cases and controls and did not reflect nutritional status during organogenesis of the neural tube. However, this is unlikely because folic acid supplementation was very infrequent in these women, and only three mothers received it during the period of neural tube organogenesis. Therefore it is unlikely that mothers of the cases were receiving multivitamin supplementation to avoid a recurrence of NTD or other adverse reproductive effects.

A further possible study limitation may be that we analysed a subpopulation of cases and controls, i.e. those for whom complete information was available on the biochemical profile and MTHFR $677 \mathrm{C} \rightarrow \mathrm{T}$ genotype. However, no differences were found between this population and the original study population in maternal characteristics associated with anencephaly that might act as confounders or covariables (age, social status, reproductive history, agricultural work, daily intake of folate and vitamin $\mathrm{B}_{12}$, use of alcohol and tobacco during the periconceptional period).

Among the main strengths of our study is that the outcome studied is one type of congenital malformation while most previous studies have analysed NTD as if they were a homogeneous group, reducing the power to find associations between the genetic marker and the disease ${ }^{(59)}$, since different NTD may have distinct aetiologies ${ }^{(60,61)}$. Thus, the main mechanism for closure of the neural tube is neurulation at the anterior pole and canalization at the posterior pole ${ }^{(62)}$. Hence, risk factors may act in different ways at distinct levels and it is more useful to evaluate the combined effect of polymorphism and folate status on a specific NTD ${ }^{(47)}$.

These results are of considerable public health interest, especially in Mexico, where there is a high risk of anencephaly, a high prevalence of $677 \mathrm{~T}$ allele and a low level of preventive interventions (e.g. periconceptional supplementation and fortification with folic acid). The percentage of NTD preventable by folic acid fortification of wheat and maize flour in 2008 was only $25 \%{ }^{(63)}$. Our study revealed that the dietary intake of folate was below the RDA for pregnant women $(600 \mu \mathrm{g} / \mathrm{day})^{(37)}$ in $83.3 \%$ of our cases and $77 \cdot 2 \%$ of controls, and the median folate intake of cases $(299 \cdot 3 \mu \mathrm{g} / \mathrm{d})$ and controls $(330 \mu \mathrm{g} / \mathrm{d})$ was about $50 \%$ of the RDA. These findings emphasize the need for folic acid supplementation and fortification programmes in the Mexican population to modify the genetic risk of having a child with anencephaly.

\section{Acknowledgements}

This project was supported by the National Council of Science and Technology of Mexico (grant number 28203-M). The authors declare that there are no conflicts of interest. Each author made a significant contribution to the paper and meets the criteria for authorship. M.L. assumes the responsibility for correspondence. The authors thank the mothers of the cases and controls, without whom the study would have been impossible. They are also grateful to the Health Services of Mexico State, Puebla and Guerrero for logistical support.

\section{References}

1. International Clearinghouse for Birth Defects Monitoring System (2008) Annual Report 2008 with Data for 2006. Rome: The Centre of International Clearinghouse for Birth Defects Surveillance and Research (ICBDSR), available at http://www.icbdsr.org/page.asp?p=10065\&l=1

2. Blatter BM, Van der Star M \& Roeleveld N (1994) Review of neural tube defects: risk factors in parental occupation and the environment. Environ Health Perspect 102, 140-145.

3. Copp AJ \& Greene ND (2010) Genetics and development of neural tube defects. J Pathol 220, 217-230.

4. Botto LD \& Yang Q (2000) 5,10-Methylenetetrahydrofolate reductase gene variants and congenital anomalies: a HuGE review. Am J Epidemiol 151, 862-877.

5. Guéant JL, Guéant-Rodriguez RM, Anello G et al. (2003) Genetic determinants of folate and vitamin $\mathrm{B}_{12}$ metabolism: a common pathway in neural tube defect and Down syndrome? Clin Chem Lab Med 41, 1473-1477.

6. Gaber KR, Farag MK, Soliman SE et al. (2007) Maternal vitamin $\mathrm{B}_{12}$ and the risk of fetal neural defects in Egyptian patients. Clin Lab 53, 69-75.

7. Félix TM, Leistner S \& Giugliani R (2004) Metabolic effects and the methylenetetrahydrofolate reductase (MTHFR) polymorphism associated with neural tube defects in 
southern Brazil. Birth Defects Res A Clin Mol Teratol 70, 459-463.

8. Suarez L, Hendricks K, Felkner M et al. (2003) Maternal serum $\mathrm{B}_{12}$ levels and risk for neural tube defects in a Texas-Mexico border population. Ann Epidemiol 13, 81-88.

9. Martínez de Villarreal LE, Delgado-Enciso I, Valdéz-Leal R et al. (2001) Folate levels and N(5),N(10)-methylenetetrahydrofolate reductase genotype (MTHFR) in mothers of offspring with neural tube defects: a case-control study. Arch Med Res 32, 277-282.

10. Christensen B, Arbour L, Tran P et al. (1999) Genetic polymorphisms in methylenetetrahydrofolate reductase and methionine synthase, folate levels in red blood cells, and risk of neural tube defects. Am J Med Genet 84, 151-157.

11. Kirke PN, Molloy AM, Daly LE et al. (1993) Maternal plasma folate and vitamin $\mathrm{B}_{12}$ are independent risk factors for neural tube defects. QJ Med 86, 703-708.

12. Wild J, Schorah CJ, Sheldon TA et al. (1993) Investigation of factors influencing folate status in women who have had a neural tube defect-affected infant. Br J Obstet Gynaecol 100, 546-549.

13. Bagley PJ \& Selhub J (1998) A common mutation in the methylenetetrahydrofolate reductase gene is associated with an accumulation of formylated tetrahydrofolates in red blood cells. Proc Natl Acad Sci USA 95, 13217-13220.

14. Boyles AL, Hammock P \& Speer MC (2005) Candidate gene analysis in human neural tube defects. Am J Med Genet $C$ Semin Med Genet 135C, 9-23.

15. Friso S \& Choi SW (2005) Gene-nutrient interactions in one-carbon metabolism. Curr Drug Metab 6, 37-46.

16. Holm PI, Hustad S, Ueland PM et al. (2007) Modulation of the homocysteine-betaine relationship by methylenetetrahydrofolate reductase $677 \mathrm{C} \rightarrow \mathrm{T}$ genotypes and B-vitamin status in a large-scale epidemiological study. J Clin Endocrinol Metab 92, 1535-1541.

17. Frosst P, Blom MJ, Lios R et al. (1995) A candidate genetic risk factor for vascular disease: a common mutation in methylenetetrahydrofolate reductase. Nat Genet 10, 111-113.

18. Weisberg I, Tran P, Christensen B et al. (1998) A second genetic polymorphism in methylenetetrahydrofolate reductase (MTHFR) associated with decreased enzyme activity. Mol Genet Metab 64, 169-172.

19. Jakubowski H, Boers GH \& Strauss KA (2008) Mutations in cystathionine $\beta$-synthase or methylenetetrahydrofolate reductase gene increase $N$-homocysteinylated protein levels in humans. FASEB J 22, 4071-4076.

20. van der Put NM, Gabreels F, Stevens EM et al. (1998) A second common mutation in the methylenetetrahydrofolate reductase gene: an additional risk factor for neuraltube defects? Am J Hum Genet 62, 1044-1051.

21. Ulvik A, Ueland PM, Fredriksen A et al. (2007) Functional inference of the methylenetetrahydrofolate reductase $677 \mathrm{C} \rightarrow \mathrm{T}$ and $1298 \mathrm{~A} \rightarrow \mathrm{C}$ polymorphisms from a large-scale epidemiological study. Hum Genet 121, 57-64.

22. Blanco-Muñoz J, Lacasaña M, Cavazos RG et al. (2007) Methylenetetrahydrofolate reductase gene polymorphisms and the risk of anencephaly in Mexico. Mol Hum Reprod 13, 419-424.

23. Mutchinick OM, Lopez MA, Luna L et al. (1999) High prevalence of the thermolabile methylenetetrahydrofolate reductase variant in Mexico: a country with a very high prevalence of neural tube defects. Mol Genet Metab $\mathbf{6 8}$, 461-467.

24. Gonzalez-Herrera L, Castillo-Zapata I, Garcia-Escalante G et al. (2007) A1298C polymorphism of the MTHFR gene and neural tube defects in the state of Yucatan, Mexico. Birth Defects Res A Clin Mol Teratol 79, 622-626.
25. Kirke PN, Mills JL, Molloy AM et al. (2004) Impact of the MTHFR C677T polymorphism on risk of neural tube defects: case-control study. BMJ 328, 1535-1536.

26. Amorim MR, Lima MA, Castilla EE et al. (2007) Non-Latin European descent could be a requirement for association of NTDs and MTHFR variant $677 \mathrm{C} \rightarrow \mathrm{T}$ : a meta-analysis. Am J Med Genet A 143, 1726-1732.

27. Shaw GM, Rozen R, Finnell RH et al. (1998) Maternal vitamin use, genetic variation of infant methylenetetrahydrofolate reductase, and risk for spina bifida. $A m J$ Epidemiol 148, 30-37.

28. Scholl TO \& Johnson WG (2000) Folic acid: influence on the outcome of pregnancy. Am J Clin 71, 5 Suppl., 1295S-1303S.

29. Harisha PN, Devi BI, Christopher R et al. (2010) Impact of 5,10-methylenetetrahydrofolate reductase gene polymorphism on neural tube defects. J Neurosurg Pediatr 6, 364-367.

30. Lacasaña M, Vázquez-Grameix $\mathrm{H}$, Borja-Aburto $\mathrm{VH}$ et al. (2006) Maternal and paternal occupational exposure to agricultural work and the risk of anencephaly. Oсcup Environ Med 63, 649-656.

31. Garcia-Closas M \& Lubin JH (1999) Power and sample size calculations in case-control studies of gene-environmental interactions: comments on different approaches. Am J Epidemiol 149, 689-693.

32. Willett WC (1998) Nutritional Epidemiology, 2nd ed. New York: Oxford University Press.

33. Hernández-Avila M, Romieu I, Parra S et al. (1998) Validity and reproducibility of a food frequency questionnaire to assess dietary intake of women living in Mexico City. Salud Publica Mex 40, 133-140.

34. Abbott Diagnostics Division (2001) IMx System Folate. Abbott Park, IL: Abbott Laboratories.

35. Abbott Diagnostics Division (1997) IMx System Vitamin B-12. Wiesbaden: Abbott Laboratories.

36. Abbott Diagnostics Division (2001) IMx System Homocysteine. Mexico DF: Abbott Laboratories.

37. Institute of Medicine (2002) Dietary Reference Intakes (DRI) for Thiamin, Riboflavin, Niacin, Vitamin $B_{6}$, Folate, Vitamin $B_{12}$, Pantothenic Acid, Biotin, and Choline. Washington, DC: National Academy Press.

38. Cech I \& Burau KD (2010) Serological differences in folate/ vitamin $\mathrm{B}_{12}$ in pregnancies affected by neural tube defects. South Med J 103, 419-424.

39. Davis BA, Bailey LB, Gregory JF et al. (1995) Folic acid absorption in women with a history of pregnancy with neural tube defect. Am J Clin Nutr 62, 782-784.

40. Ren A, Zhang L, Hao L et al. (2007) Comparison of blood folate levels among pregnant Chinese women in areas with high and low prevalence of neural tube defects. Public Health Nutr 10, 762-768.

41. Mitchell LE, Duffy DL, Duffy P et al. (1997) Genetic effects on variation in red-blood-cell folate in adults: implications for the familial aggregation of neural tube defects. $A m \mathrm{~J}$ Hum Genet 60, 433-438.

42. Molloy AM, Mills JL, Kirke PN et al. (1998) Whole blood folate values in subjects with different methylenetetrahydrofolate reductase genotypes: differences between the radioassay and microbiological assays. Clin Chem $\mathbf{4 4}$, 186-188.

43. Narayanan S, McConnell J, Little J et al. (2004) Associations between two common variants C677T and A1298C in the methylenetetrahydrofolate reductase gene and measures of folate metabolism and DNA stability (strand breaks, misincorporated uracil, and DNA methylation status) in human lymphocytes in vivo. Cancer Epidemiol Biomarkers Prev 13, 1436-1443.

44. Perez AB, D'Almeida V, Vergani N et al. (2003) Methylenetetrahydrofolate reductase (MTHFR): incidence of mutations 
C677T and A1298C in Brazilian population and its correlation with plasma homocysteine levels in spina bifida. Am J Med Genet $A$ 119, 20-25.

45. Li D, Pickell L, Liu Y et al. (2006) Impact of methylenetetrahydrofolate reductase deficiency and low dietary folate on the development of neural tube defects in splotch mice. Birth Defects Res A Clin Mol Teratol 76, 55-59.

46. Bennett GD, Vanwaes J, Moser K et al. (2006) Failure of homocysteine to induce neural tube defects in a mouse model. Birth Defects Res B Dev Reprod Toxicol 77, 89-94.

47. Padmanabhan R, Shafiullah M, Benedict S et al. (2006) Effect of maternal exposure to homocystine on sodium valproate-induced neural tube defects in the mouse embryos. Eur J Nutr 45, 311-319.

48. Heidenreich DJ, Reedy MV \& Brauer PR (2008) Homocysteine enhances cardiac neural crest cell attachment in vitro by increasing intracellular calcium levels. Dev Dyn 237, 2117-2128.

49. Blom HJ (2009) Folic acid, methylation and neural tube closure in humans. Birth Defects Res A Clin Mol Teratol 85, 295-302.

50. Wilson A, Platt R, Wu Q et al. (1999) A common variant in methionine synthase reductase combined with low cobalamin (vitamin $\mathrm{B}_{12}$ ) increases risk for spina bifida. Mol Genet Metab 67, 317-323.

51. Lucock M, Daskalakis I, Hinkins M et al. (2001) An examination of polymorphic genes and folate metabolism in mothers affected by a spina bifida pregnancy. Mol Genet Metab 73, 322-332.

52. Relton CL, Wilding CS, Pearce MS et al. (2004) Gene-gene interaction in folate-related genes and risk of neural tube defects in a UK population. J Med Genet 41, 256-260.
53. O'Leary VB, Mills JL, Pangilinan F et al. (2005) Analysis of methionine synthase reductase polymorphisms for neural tube defects risk association. Mol Genet Metab 85, 220-227.

54. Blom HJ, Shaw GM, den Heijer M et al. (2006) Neural tube defects and folate: case far from closed. Nat Rev Neurosci 7 , 724-731.

55. Bruinse HW \& van den Berg H (1995) Changes of some vitamin levels during and after normal pregnancy. Eur $J$ Obstet Gynecol Reprod Biol 61, 31-37.

56. Cikot RJ, Steegers-Theunissen RP, Thomas CM et al. (2001) Longitudinal vitamin and homocysteine levels in normal pregnancy. Br J Nutr 85, 49-58.

57. McPartlin J, Halligan A, Scott JM et al. (1993) Accelerated folate breakdown in pregnancy. Lancet 341, 148-149.

58. O'Rourke KM, Redlinger TE \& Waller DK (2000) Declining levels of erythrocyte folate during the postpartum period among Hispanic women living on the Texas-Mexico border. $J$ Womens Health Gend Based Med 9, 397-403.

59. Relton CL, Wilding CS, Jonas PA et al. (2003) Genetic susceptibility to neural tube defect pregnancy varies with offspring phenotype. Clin Genet 64, 424-428.

60. Khoury MJ, Erickson JD \& James LM (1982) Etiologic heterogeneity of neural tube defects: clues from epidemiology. Am J Epidemiol 115, 358-548.

61. Detrait ER, George TM, Etchevers HC et al. (2005) Human neural tube defects: developmental biology, epidemiology, and genetics. Neurotoxicol Teratol 27, 515-524.

62. Elwood JM, Little J \& Elwood JH (1992) Epidemiology and Control of Neural Tube Defects. Oxford: Oxford University Press.

63. Bell KN \& Oakley GP Jr (2009) Update on prevention of folic acid-preventable spina bifida and anencephaly. Birth Defects Res A Clin Mol Teratol 85, 102-107. 